\title{
Promoting a capability approach and impacting social justice through a wellbeing framework: a case study of VET reform in Georgia
}

\author{
Nata Kereselidze, Haute école spécialisée de Suisse occidentale \& Université de Genève \\ Isabel Voirol-Rubido, Université de Genève
}

\section{DOI : 10.51186/journals/ed.2021.11-1.e428}

\begin{abstract}
Georgia is currently undergoing a VET reform, bringing together public, private, and social actors, based on the principle of solidarity. This paper aims to identify ways in which the Georgian VET reform can be a force for economic prosperity, as well as wellbeing for different communities. Results are presented through a comprehensive research methodology, mobilizing a state of the art through in-depth analysis of primary and secondary data sources, as well as seven semi-structured, face-to-face interviews with education practitioners and policymakers in Georgia. The article highlights how progress is hindered by a peculiar mix of Soviet era and neo-liberal legacies that has shaped a unidimensional human capital approach focused on economic growth. We suggest limitations to this approach, and instead propose to re-align the system towards the objective of wellbeing, employing a Social Return on Investment (SROI) framework and advocating for collectivized intelligence between actors. Through an innovative meta-theoretical framework, we emphasize the importance of historical path-dependency and lay out the context. We analyze stakeholder interviews through the SROI framework and suggest socially-minded changes, benefiting individuals and the society as a whole.
\end{abstract}

Keywords: capability approach, education policy, Georgia, social justice, VET reform

\section{Résumé}

Une réforme du système de formation professionnelle est actuellement en cours en Géorgie impliquant les acteurs/trices privé-es, publics/ques et sociales/aux selon le principe de solidarité. Cet article interroge cette réforme sur son potentiel à soutenir la prospérité économique du pays et le développement du bien-être de sa population. II s'appuie sur une revue de la littérature concernant les politiques de formation professionnelle, ainsi que sur les résultats d'une analyse de contenu de données primaires et secondaires concernant la réforme entreprise en Géorgie, et sur sept entretiens semi-structurés avec des responsables politiques et praticien-nes de la formation professionnelle en Géorgie. Les résultats soulignent 
le poids de l'héritage socioculturel soviétique et des préceptes néolibéraux qui façonnent une vision unidimensionnelle du capital humain mettant en péril les objectifs visés par la réforme. ॥ met en évidence les limites de cette démarche et propose de réaligner le système vers l'objectif de bien-être, en mobilisant le modèle de Retour Social sur Investissement (RSSI) centré sur un principe de solidarité et d'intelligence collective mobilisant les acteurs concernés par la réforme. II suggère finalement des changements à visée sociale bénéficiant aux individus et à la société dans son ensemble.

Mots-clés : approche de " capability », Géorgie, justice sociale, politique éducative, réforme de FP

\section{CONTEXT AND OBJECTIVES OF RESEARCH}

The happiest societies in the world are ones where human beings can utilize their capabilities to the fullest, in the pursuit of creating a lifestyle they have reason to value. In societies where social justice is the end goal, people enjoy the possibility of continuous personal improvement towards a happier personal life, and therefore, a happier social existence, valuing progress for the sake of wellbeing (Bell, 2007; Tyson, 2016). The freedom to choose one's path in life, through social structures that support the expansion of the capabilities of human beings, should be the objective of any society (Fraser, 2004; Grant et al., 2013; Moodie et al., 2018).

In reaching such an ideal, vocational education and training (henceforth, VET) can play a leading role, focusing on an individual's holistic development (Shirley, 2020). The complexity, however, lies in popularizing a controversial human-focused framework, rooted in the philosophy of social justice, that goes against the established unidimensional model of human capital theory (Becker, 1993), and expands the approach to one that considers more diverse processes and outcomes through the capability approach (Robeyns, 2017). This paper aims to enrich the dialogue on social justice in education through the lesser-known case of Georgia and its ongoing VET reform, by inquiring into (i) the structural and institutional needs of the reform to solidify VET as a central element of Georgia's economy, and (ii) the extent of policy reformulation needed to focus on human development on a larger scale. Although the reform already has clear neoliberal undertones favoring growth, we feel the need to articulate its raw potential that could simultaneously serve the wellbeing of individuals and contribute to social justice for all.

After its revival in the early 2000s, the VET sector received a considerable boost in resources in 2013, from international donors like the German Development Cooperation (GIZ) and the Swiss Development Cooperation (SDC), and its development strategy took off. Georgia's VET history, however, has not been an easy one. Early attempts at creating craftsmen's guilds and unions for sector-specific development through apprenticeship-style teaching and learning 
were cut short (Tumanishvili \& Omsarashvili, 2016) due to political turmoil in the early 1920s, transforming a social-democratic government into a totalitarian communist system. After regaining independence in 1991, the Georgian government went through a restructuring process, as did its economy, integrating free market principles (Matsaberidze, 2019). Although much of Soviet legacy remained (Gegenava, 2017), VET once again became synonymous with labor market insertion. Today, due to the lingering negative memories of Georgia's soviet past, professional routes in education are still stigmatized. As a result, there is a tendency to undervalue individuals with VET degrees, which discourages VET participation and presents barriers to smooth transitions into the labor market (Omanadze et al., 2017). Despite objectives of the reform to dispel negative attitudes towards VET, establish public-private partnerships (henceforth PPPs) for adequate skills-matching, and address the expansive informal sector negatively influencing human progress, policymakers could better utilize its platform to incorporate wellbeing indicators into the overall policy framework for a more human-focused impact.

Having set the ground for further discussion in chapter 1, we introduce an innovative theoretical meta framework in chapter 2, where we argue for the functionality of the capability approach in Georgia. Our methodology is outlined in chapter 3, followed by our findings and conclusions in chapters 4 and 5. The last two chapters revolve around our analytical framework that offers alternative approaches to governance and policymaking, borrowing from the philosophy of social justice and by extension, the capability approach.

\section{META FRAMEWORK OF THE CAPABILITY APPROACH}

The capability approach, as a tool for structural change, prioritizes a holistic development of the individual, targeting individual and social wellbeing (Sen, 2000; 2005). As a theoretical base, it is well suited for the understanding of a reform process in education in a development context characterized with other sectoral particularities. To accentuate its applicability to the case of Georgia, our capability approach will incorporate elements of: human capital theory, emphasizing the importance of a skilled labor market for sustainable productivity; personal capital theory, outlining the impact of a fast-changing labor market on the choices people make in their professional lives; and cultural capital theory, stressing the impact of social origin on the ability to turn capabilities into achievements benefiting the individual. 


\subsection{The Capability Approach as Public Policy}

As an alternative to the wellbeing approach or other resource-based theories of justice, the capability approach focuses on the freedoms and achievements ${ }^{1}$ of an individual, allowed by functioning social structures (Moodie, et al., 2019). It measures human development through the lens of wellbeing, instead of economic growth - an exhausted indicator that does not only ignore individuals' quality of life, but further increases inequalities between local and global communities (Hickel, 2017). Apart from its goal to close gender and class gaps in access to education, as well as adjust gender and class pay gaps in later employment, the capability approach can help individuals make more sustainable choices guided by their own wellbeing and the wellbeing of their surroundings (Hickel, 2020; Sen, 1990). In a multi-stakeholder system, comprised of public, private, and independent actors, it is, above all, imperative that the basic conditions of social justice be understood and shared. In the Georgian context, the capability approach can be a force towards collective decision-making on a policy level and can allow for better decision-making on an individual level.

\subsection{Rethinking Elements of the Capability Approach}

To fully embrace the capability approach, we must consider the elements that it has rethought to enable the creation of socially just policies. Firstly, Becker's (1993) Human Capital Theory, that correlated growth in income with increase in education and training, can no longer be seen in the same light in today's instable economic climate, where people are increasingly subject to the job precarity of a freelance worker (Ludwig-Mayerhofer, et al., 2011; Nachtwey, 2016; Raphael, 2019). Granted, investment in human capital is crucial in production and service sectors, but it cannot be equitable without consideration of human wellbeing in the larger sense. ${ }^{2}$ Secondly, Boltanski and Chiapello's (1999; 2005) Personal Capital Theory and the project-to-project transition model, which describes an innovative shift to skills-acquisition through mobility leading to work autonomy and network-based job security, downplays the fact that these processes also increase work precarity for most people. They create gaps between different social strata and add to informality in an increasingly unreliable labor market. Without a network or employer that provides information and offers guidance to develop one's competencies, individual equity in opportunity suffers. Permanent adaptability and skills-matching is challenging even for countries with adequate systemic and technological readiness. Operationalizing personal capital theory in Georgia, a formerly communist society with a newly liberalized market economy, can yield much more harmful effects on social cohesion and social justice (Klein, 2007). Thirdly, Bourdieu and

\footnotetext{
1 Freedoms and achievements can also be referred to as capabilities and functionings, as what people are capable of doing and being vs. what they are managing to do and to be. In other words, achievements/ functionings depend on people's realistic choices, molded by their life experience and structural surroundings. (Nussbaum, 2011; Robeyns, 2017).

2 Human wellbeing in the larger sense includes physical and psychological health, in many ways determined by our environment and ecological conditions. Widening awareness about climate change and individual actions necessary to alleviate it should be included in any national reform, including if not especially, in education. See: Martusewicz, et al. (2014) and Winograd (2016).
} 
Passeron's (2000) Cultural Capital Theory, which uncovers the power-based division of resources reproduced through path-dependency, demonstrates how people from lower social classes (especially in countries where few or no governmental structures exist) are held back from similar professional and personal achievements as their privileged counterparts. The universal applicability of this theory helps explain existing inequalities and understand the need for the Capability Approach as a solution towards human wellbeing.

\section{METHODOLOGY}

This research tries to identify ways in which the Georgian VET reform has the potential to be a force for economic prosperity, as well as to improve the wellbeing for different communities. By considering the capabilities that need to be operationalized for the reform to reach its maximal potential, the paper analyzes the extent of structural change needed to harness collective actor intelligence on different levels of policymaking. The paper also aims to show that these processes are inevitable harbingers of productivity and sustainable economic profitability. With these objectives in mind, the following qualitative research design plan (Hennink, et al., 2020) was developed.

\subsection{Design and Method}

After an in-depth analysis of primary and secondary data sources, specifically: legislative documents, governmental strategy reports, academic books and articles, and institutional reports, a state of the art was developed, focusing on recent global developments within work-based learning and school-to-work transitions in VET.

Semi-structured, face-to-face interviews were conducted (Blanchet \& Gotman, 2015) with a group of education practitioners and policymakers in Tbilisi. Stakeholder profiles are outlined in figure 1 , below. 


\section{Figure 1. Stakeholder Guide}

\begin{tabular}{|c|c|c|c|}
\hline Code & Sex & Nature of Work & Institution Represented \\
\hline$S 1^{1}$ & $\mathrm{~F}$ & Civil Servant & MoESCS2 \\
\hline S2 & $\mathrm{F}$ & Civil Servant & MoESCS \\
\hline S3 & $\mathrm{F}$ & VET Expert & $G \mid Z^{3}$ \\
\hline S4 & $\mathrm{F}$ & $\begin{array}{l}\text { At the time of interview: VET Expert; } \\
\text { Currently: High-level Civil Servant }\end{array}$ & $\begin{array}{c}\text { At the time of interview: UNDP4; } \\
\text { Currently: MoESCS }\end{array}$ \\
\hline S5 & M & VET Expert & GFA $^{5}$ \\
\hline S6 & M & Director & ITVET6 \\
\hline S7 & $M$ & Director & VET College "Georgia" \\
\hline
\end{tabular}

Source: Authors' own illustration

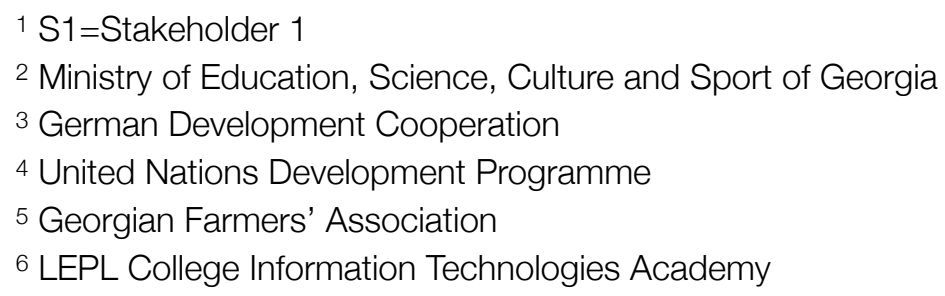

An interview guide and a rough interview questionnaire were developed, where questions were devised using information from the state of the art, ensuring wide application to different stakeholders. Real-time conversations with experts actively engaged in the reform process broadened the perspectives of research on the contextual truths beyond initial objectives. The data was then coded and analyzed thematically through a qualitative analysis software, which grew into the respective sub-chapters of chapter 4.2, demonstrating how the Social Return on Investment (SROI) framework - a development tool measuring positive social impact of new policies (Vardakoulias, 2013) - can be operationalized to unlock individual capabilities towards social wellbeing.

\subsection{Limitations}

Due to resource limitations for our research, we considered a small stakeholder sample, without the option of generalizing the results to a wider stakeholder makeup involved in the reform. Moreover, as qualitative analyses are not standardized, it would be unrealistic to reproduce the same exact results a second time. We recognize that stakeholders have a vested interest in the reform, and that they may have presented certain views to highlight their own role, not always considering their own limitations. We try to remedy this bias throughout the analysis by comparing individual accounts with existing literature in the field. However, as 
the topic is under-researched, there is little context-specific independent literature to validate claims. While we recognize that a broader labor market analysis would have benefited this research, it would have been beyond the scope of this paper, all the more so, because the reform is ongoing and potential socio-economic effects are not yet discernable in the data.

\section{FINDINGS}

At a time when self-reliance, autonomy, and tight-knit networks are essential preconditions of employability, VET can play an important role in guiding individuals towards continuous selfdevelopment. VET can also be instrumental in reducing informal professional activity and establishing new networks, while lifting the strain of inequality off of the economy. Considering personal and social wellbeing as the end-goal of the ongoing VET reform in Georgia, it is imperative that the logic of the reform fit the needs of the context at hand. As there is no unique model of an education reform, its effectiveness depends on the legislative freedoms permitted by the system, its cohesion with other fields of policy, and the availability of resources and time to produce expected outcomes. Recent research (Bardi \& Véran, 2020; De Ketele, 2020a; 2020b; Meuret, 2020) shows the importance of collectivized intelligence for effective governance, where analytical thinking is shared and comparisons are made based on precedent. This means garnering the strength of public, private, and individual actors and granting them autonomy as needed. The success of such a strategy depends on the institutional setup through which implementation takes place. But, as institutions are highly path-dependent (North, 1990), positive change may take a long time.

\subsection{Rethinking Labor Market and Education Policies}

Currently, the Georgian labor market falls short of many essential standards and regulations that hold employers responsible in their relationship with employees. Economic instability aggravates the quality of these relationships, as most employers search for quick solutions and avoid committing to future staff development. This eroded employment relationship is partly responsible for low productivity, which could be fostered by more practice-oriented learning paths and longer job tenure of more satisfied workers. Due to the persisting low employment creation conditions, the Georgian government is continuously partnering with donor organizations, like GIZ and SDC to renew support programs for micro, small, and medium-sized enterprises (MSMEs). As there is also a large informal MSME market in Georgia, development programs should extend to them as well, so as not to lose the production value and human capital that can add to overall prosperity, but to also ensure the wellbeing of informal workers (Sepulveda \& Syrett, 2007). Through PPP, enterprises, together with the state, should start thinking about activation policies to revitalize older generations and revive discouraged workers, building their employability (Béduwé \& Mora, 2017; Wittorski, 2008; 2011). 
VET's reputation as the place for underachievers has stuck with the Georgian public for decades. Before the reform, taking a professional track meant being cut off of the main educational route after only nine years of schooling. Today, as part of the reform, three-year professional tracks have been integrated into the main educational route, giving students choice between general secondary, general professional, and general secondary plus professional routes within grades ten to twelve. All students can now graduate with a similar secondary level diploma, opening doors towards higher levels of education ${ }^{3}-$ a systemic merger that did not exist before. With the aim of widening VET reach, short certification training and re-training courses were developed in parallel, targeting older generations and their professional development, orientation, or reorientation. Policymakers simultaneously developed mechanisms to approve non-formal and informal learning (Government of Georgia, 2020a; MoESCS, 2019), giving individuals the opportunity to fast-track their professional or educational advancements, on par with the activation policies described in the paragraph above.

Although the reform has rolled out innovative proposals and nudged the education system towards a complete revival, it's overall aim still lacks clarity. A vision built on social justice will be presented in 4.2, together with an analytical framework as a model for clear policy operationalization.

Long discussions between different stakeholders resulted into a decision to establish a workbased learning (WBL) (Cedefop, 2015) VET framework, integrating dual models where possible and accommodating other forms where there are no alternatives (S4). ${ }^{4}$ This decision was inevitable given that educational institutions are perceived as more dominant and enterprises are largely unable or unwilling to commit to apprenticeship contracts that would tie them down to strict workplace rules (S1, S3, S4, S5). Such a broad framework, however, requires strengthening local governance, to avoid the shortcomings of prior centralized planning efforts. A wish for more local autonomy was also highlighted by local stakeholders, to overcome the instability of national political institutions (S6). To date, local stakeholders have been limited in their engagement in process design, leaving local, community-based potentials unexplored.

\footnotetext{
3 See: National Center for Educational Quality Enhancement. Accessed: February 5, 2021. The VET metaframework shows the interconnectedness of different educational levels throughout the education system.

${ }^{4}$ One example of a non-dual, work-based learning model is beekeeping. The beekeeping sector is comprised of small enterprises and independent entrepreneurs, most of them members of a cooperative. The objective of cooperatives is growth, wherefore their focus is on getting more members, not hiring more employees. For the specific case of beekeeping, the Georgian Farmers Association (GFA) has been working on a special apprenticeship contract accommodating the principles of WBL according to which each apprentice will receive a beehive and bee families towards the end of their apprenticeship. This way more people are able to enter the trade, start their own business, and become a member of a cooperative (S4, S5). Such an alternative to a classical dual model is seen as valuable for the development of the sector (Government of Georgia, 2020b).
} 


\subsection{Social Return on Investment}

To operationalize the idea of collective intelligence in policymaking and governance, we present a social return on investment (SROI) framework of analysis. Based on the principle of good life, SROI goes further than a traditional cost-benefit analysis (CBA), 5 in that, it tries to implicate all relevant stakeholders in a given reform to ensure that the voices of those affected are heard, and their needs met. However, like a traditional CBA, SROI must also be monetarily valued (an exercise we cannot and do not attempt here, but suggest exploring through an abstract model below) through appropriate social and wellbeing indicators, which could be a challenging task, due to their intangible market value ${ }^{6}$. This, we think, is a challenge worth exploring, for the sake of illustrating the positive and negative impacts of such a reform on society at large in a holistic manner. This chapter will present SROI as an expanded development framework for Georgia, incorporating the VET reform and extending its impact to societal wellbeing.

Figure 2 represents an inverted triangle flowchart illustrating components of each broad level of policymaking. Although the layout is constructed on a macro level, systemic relationships, as well as important actions, outlined on each level, give clear indications of the groups that are affected on meso and micro levels. Below, we critically look at the needs of each stage of policymaking and discuss synergies between the actors and actions involved, building up to social indicators that can be introduced for wellbeing as an end goal. We also consider indirect effects on different groups. Throughout the discussion, the SROI framework will shed light on important connection points ${ }^{7}$ between actors and actions, working in solidarity towards a specific outcome. While the flowchart proposes specific actors and actions towards the achievement of each level of progress, it does not rule out alternative propositions. It is conceived as a model, suggesting elements that could be considered in the quest to achieve wellbeing. The most important takeaway is that each outcome can only be achieved through a collaborative effort between multiple actors from both public and private sectors. This collaborative structure is still in many ways a novelty in Georgia, where the legacy of the education system is one of state centrism.

\footnotetext{
5 "CBA is the predominant tool used in welfare economics in order to assess whether an intervention - be it a project or policy - should be undertaken or not. The criterion for an intervention to be undertaken is that its' benefits outweigh its' costs"(Vardakoulias, 2013, p. 1).

6 For further information about social and wellbeing indicators, see footnote 16 under chapter 4.2.6.

7 The connection points are alphabetized and the letters are allotted respective explanations, following a logical relationship between actors.
} 


\section{Figure 2. SROI Framework of Georgia's VET Reform}

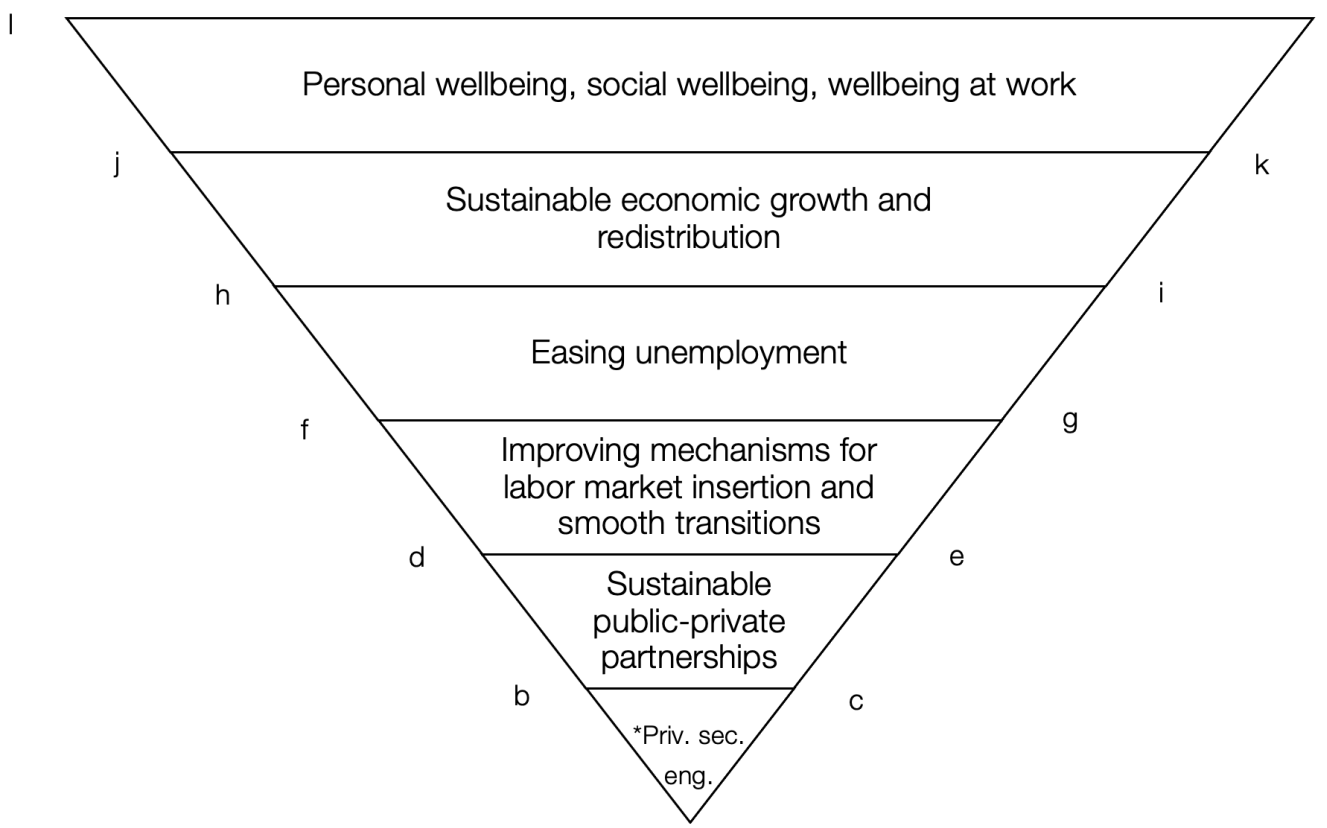

Actors and Actions in the System

\section{*Private Sector Engagement}

$\mathrm{a}=$ VET colleges

$\mathrm{b}=$ Ministry of Education Science Culture and Sport (MoESCS)

$\mathrm{c}=$ Chamber of Commerce and Industry/ Employers' associations

Sustainable Public-Private Partnerships

$\mathrm{b}=$ Ministry of Education Science Culture and Sport (MoESCS)

$c=$ Chambers of Commerce and Industry/ Employers' associations

$d=$ Legal framework ( de jure and de facto ) accounting for worker

$\mathrm{e}=$ National Center for Education Quality Enhancement (NCEQE)
Easing Unemployment

$f=$ VET colleges

$\mathrm{g}=$ Enterprises

$\mathrm{h}=$ Training and re-training

$\mathrm{i}=$ Employment initiatives for disadvantaged groups

Sustainable Economic Growth and Redistribution

$\mathrm{h}=$ Training and re-training

$\mathrm{i}=$ Employment initiatives for disadvantaged groups

ight $\mathrm{j}=$ Government investment in public services

$\mathrm{k}=$ Enforcing taxation on non-tradable sectors

Improving Mechanisms for Labor Market Insertion and Smooth Transitions Personal Wellbeing, Social Wellbeing, Wellbeing at Work

$\mathrm{d}=$ Legal framework ( de jure and de facto ) accounting for workers' right $j$ = Government investment in public services

$\mathrm{e}=$ National Center for Education Quality Enhancement (NCEQE) $\quad \mathrm{k}=$ Enforcing taxation on non-tradable sectors

$\mathrm{f}=\mathrm{VET}$ colleges

$\mathrm{g}=$ Enterprises

I = Establishing a healthy work-life balance and work leave

$\mathrm{m}=$ Higher wage growth and improved livelihoods through higher productivity

How to read the chart: Ex. From the tip of the triangle (private sector engagement): To achieve private sector engagement within an equitable partnership of stakeholders, three key players must be present: a) VET colleges, b) the Ministry of Education, Science, Culture and Sport (MoESCS), and c) the Chamber of commerce and industry of Georgia, as well as sectoral associations. This triangulation of responsibilities ensures equity, efficiency, and effectiveness in established public-private partnerships. The flowchart follows the same logic throughout. The higher levels of collaboration become quadrangulation of responsibilities between actors.

Source: Authors' own illustration

\section{Private Sector Engagement}

Private sector engagement in the context of Georgia is indispensable. Without it the economy cannot function efficiently. At an estimated 99.72 percent in 2017, Georgia's economic makeup is nearly exclusively micro, small and medium-sized enterprises (MSMEs) (OECD, 2019). MSMEs provide and create most jobs, not to mention that they have the highest 
employment growth rates (ILO, 2019a). They carry the important responsibility of developing entrepreneurial talent by training young people and their active engagement enhances competition, initiates growth, and makes economies more efficient and innovative (de Kok et al., 2013). In contrast to central and northern European countries, MSMEs in Georgia are born out of necessity for subsistence and operate with low productivity in market segments that are hard to access. Many of these firms are also informal, which keeps them from creating partnerships with VET schools and hence, disables their social and economic role within the society. Such firms secure livelihoods, but often do not create decent jobs, nor do they contribute to the growth and sustainability of the economy as a whole. Optimistic estimations would indicate that initial private sector engagement efforts would encourage other enterprises to also participate, benefiting the broader economy by improving labor market relevance and increasing worker retention. Such developments would solidify publicprivate partnerships (PPPs) and increase wellbeing at work ${ }^{8}$, adding to workers' future economic opportunities. Yet, too much of the government strategy remains implicit, leaving one to assume that the intention is to improve the overall labor market and training situation through spillover effects and a trickle-down approach.

\section{Sustainable Public-private Partnerships (PPPS)}

Establishing partnerships between enterprises and VET colleges in Georgia is a hit-and-miss practice $(\mathrm{S} 3, \mathrm{~S} 7)$. This is because of a lack of risk-taking from the side of enterprises, which, in turn, is due to weak regulatory patterns in the labor code (Government of Georgia, 2010), and now, weak regulatory patterns in the WBL framework as well. The inconsistencies in the quality of WBL that have existed so far, largely due to the government's neo-liberal approach to economic development and its soft relationship with business, creates distrust from all sides. Given that trust is a prerequisite for the functioning of WBL, government policies towards legislative easing seem counter effective. If the system is too flexible, comparability of learning will suffer and workers' conditions will risk becoming precarious, undermining a fundamental aim of the VET system.

Stakeholders that support the approval of a flexible regulatory framework of WBL argue, that one, it would allow for a wider participation of MSMEs in WBL provision, encouraging sectoral development, and two, that it would convince enterprises to engage in WBL program design and provision (S4, S5). On the other hand, stakeholders that do not support the approval of a loosely regulated framework, argue for the importance of work safety and decent pay through a clearly delimited student/apprentice status. They fear that giving businesses precisely what they want only fuels their arrogance, which does not make for equitable PPPs (S1, S6). There is substantiated fear that enterprises might abuse the guise of apprenticeships to replace standard workers, thereby also threatening the employment relationship. The difficulty of

\footnotetext{
8 A wellbeing indicator that can be measured through personal accounts on, for example: work satisfaction,
} feeling valued at work, or feeling safe at work. 
negotiating with enterprises halts the division of responsibilities amongst public and private actors, which does not help improve educational or occupational standards. ${ }^{9}$ Standard improvement would also improve acquisition of occupational and transferable skills, developing in-depth understanding of one's craft, but also remaining adaptable in the market (Badurashvili, 2019; ETF, 2019; Palmer, 2020). Pairing occupational and transferable competences is crucial not only for human capital development, but also for the development of capabilities, through which individuals can build their desired lifestyles. Another element impeding standards improvement is the centralized regulation of VET colleges. College directors noted that with rigorous quality control cycles, more autonomy would be the harbinger for more effectiveness and efficiency in college governance (S6, S7).

The absence of a mechanism facilitating cooperation between enterprises, ministries, and VET colleges on questions like regulatory mechanisms in WBL, standards improvement, and decentralization of VET governance has negatively affected sustainability of PPPs. Recently, an agreement was reached between the Ministry of Education, Science, Culture and Sport (MoESCS) and the Georgian Chamber of Commerce and Industry (GCCl) to jointly found an agency to fill that missing link. Following a functional analysis and planning of its structure, the agency is expected to take effect sometime in 2021 (S1). Following the COVID 19 crisis and a noticeable reduction of the initially approved budget, public and private partners, implicated in the founding of the agency, are now lobbying for more donor support, to ensure quality in the initial implementation phase.

\section{Improving Mechanisms for Labor Market Insertion and Smooth Transitions}

Activities within the reform, that aim to improve labor market insertion and smooth school-towork-and-back transitions, are built on the principle of lifelong learning. Supporting people's holistic development, lifelong learning also plays a crucial role in ensuring a person's dignity (Champy-Remoussenard, 2015). The state and enterprises have the responsibility to guide workers to participate in trainings within or outside firms (ILO, 2019b). Research suggests that the quality of an employment relationship - i.e. whether it is precarious or not influences the availability of lifelong learning opportunities to workers (Aleksynska, 2018; ILO, 2016).

Specific projects designed to systematize the lifelong learning principle are described in 4.1. The parallel development of short training and re-training programs, catered to adults, and long secondary-level integrated programs, catered to the youth, targets specific age groups and allows for smoother transitions. While such policies improve economic efficiency and

\footnotetext{
9 One way of improving educational and occupational standards, while ensuring a division of responsibilities between public and private stakeholders is through the DACUM (Developing a Curriculum) process (Jacobs, 2019; Norton \& Moser, 2008). The DACUM methodology was first introduced in Georgia in 2015, where occupational standards were developed through a large-scale market analysis in eleven regions, spanning sixthousand public and private sector organizations (MoESCS, 2015).
} 
ease unemployment, they more importantly increase the capabilities of individuals, and therefore make a fundamental contribution to their personal wellbeing. ${ }^{10}$ Systematizing such learner-focused approaches should therefore be at the forefront of policymakers' thinking.

\section{Easing Unemployment}

As the reform is still in its initial stages, meaningful change has not yet been reflected in unemployment numbers. While, according to the latest tracer study, labor market insertion from the VET sector has increased from 42\% to 62\% between 2014 and 2019 (ACT, 2019; MoESCS, 2014), the overall unemployment numbers have not improved. In the age-group 18-35, overall unemployment increased from 35\% to 36\% between 2013 and 2019.11 These are of course also affected by other factors, such as the business cycle, and are bound to substantially worsen as a result of the ongoing labor market crisis induced by the COVID-19 pandemic.

Different stakeholders argued that the reason for these numbers was an absence of work ethic and general lack of motivation among young people in Georgia (S4, S7). They implied that individuals just need to work harder and become more resilient for the economy to grow more sustainably, ignoring cultural factors as well as historic and institutional specificities that are often engrained in the social structure through unwritten norms and behaviors (Acemoglu, et al., 2005; Acemoglu \& Robinson, 2012; Biavaschi, et al., 2012; Greif, 2006; North, 1990). This distinction between an individual choice taking place in a decision-making vacuum unimpeded by outside factors, or it taking place under consideration of the mores and cultural factors of the country is an important one, because the former view is a reflection of a deeply entrenched absorption of a neoliberal view of individualism in society. La Porta, et al. (1999) have argued that in order to explain the heterogeneity of institutions among countries, one has to consider a broader set of factors, including economic, political and cultural ones. A study of post-soviet countries affirms this theory, highlighting that all three factors play a fundamental role in how labor market outcomes are shaped (Pilc, 2017).

Keeping in mind the three factors mentioned above, there are several ways in which unemployment can be eased, contributing to sustainable economic growth.

As a first condition, there should be adequacy between qualifications and educational and occupational standards, setting the ground for further action. Subsequently, systemization of Active Labor Market Policies (ALMP) - traditionally serving school-leavers through career advice and supporting adults through professional orientation - would improve labor market relevance. ALMPs are a proven way to decrease VET drop-out rates, and instead increase

\footnotetext{
10 A wellbeing indicator that can be measured through personal accounts on, for example: emotional wellbeing, satisfying life, and resilience and self-esteem.

11 See: CRRC (Caucasus Barometer). Accessed: 25 June, 2020.
} 
targeted labor market insertion. Its methodology has already been introduced in Georgia by GIZ, and its realization is on a developmental phase, soon to be integrated in the larger VET reform (S3). A related activity would be to expand the function of the Tracer Study - a report prepared every four to five years, describing indicators of labor market integration of VET graduates. Ministry representatives are already considering to increase the frequency of its publication to an annual format (S1, S2). A step even further would be to develop Labor Market Information Systems (LMIS), a system of datasets coordinating supply and demand within the labor market. LMIS are important for the development of employment and labor policies, ensuring better quality results based on sound evidence. ${ }^{12}$ Due to data and resource constraints, operationalization of LMIS remains a long-term ideal for now (S3).

\section{Sustainable Economic Growth and Redistribution}

Measures discussed above, to improve labor market insertion, have a positive effect on the sustainability of economic growth. Growth, of course has arbitrary limits, beyond which policymakers' attention should shift to sustainability and redistribution policies. For a country like Georgia however, growth on a per capital level still means improvements in the standards of living and thus improvements in people's overall wellbeing. The main objective of economic growth should be to support this end. The SROI framework, as an outgrowth of the capability approach presented in figure 2, is used to evaluate potential policies that could create pathdependency. For example, at this level, lifelong learning could expand individual capabilities for project-to-project transition, allowing people to contribute to overall economic growth, but also to gain more autonomy and dignity in their work environment; Employment initiatives for disadvantaged groups could free up public resources, which would otherwise be directed towards their support. The goal of these initiatives would be to re-route people's lives into stable routines, improving their capabilities to enter into productive employment in the longterm; Investment in public services could improve the functioning of services and infrastructure for the benefit of the people, which is also indispensable for growth and generates domestic demand. Other similar policies can be designed with the reduction of inequality and the increase of social wellbeing ${ }^{13}$ in mind.

\section{National Accounts of Wellbeing}

The last stage, and desired impact level of the current VET reform shows wellbeing at large as the aim of public policy towards a happier society (Layard, 2005). As facilitators of continuous and sustainable progress (Diener \& Tov, 2012), happiness measures are important to complete the final wellbeing cycle. Once achieved, they will flow through the illustrated logical framework as capabilities ready to become equal functionings (or freedoms ready to

12 See: ILO (Decent Work for Sustainable Development: 14 Labour Market Information Systems). Accessed: 6 August, 2020.

${ }^{13}$ A wellbeing indicator that can be measured through personal accounts on, for example: feeling of trust and belonging. 
become equal achievements). For example, establishing a healthy work-life balance enables people to recharge and return to work with renewed excitement, fueling their productivity. Productive people, in turn, have a higher potential for wage growth, which improves their livelihoods and their overall personal, social, and occupational wellbeing. This last nexus brings us to consider a new movement in wellbeing economics, called the National Accounts of Wellbeing - a revolutionary approach in policymaking that bases its philosophy on social justice and environmental sustainability (NEF, 2009), at the core of which stands a dynamic VET sector and an inclusive labor market, unlocking individuals' capabilities for continuous personal and professional growth.

National Accounts of Wellbeing is a proposal to improve national welfare and support a good life of citizens. The notion was born seventy-five years ago through insights from different social sciences (Robeyns, 2017), with the aim to substitute economic indicators like GDP, ${ }^{14}$ insufficient when assessing state welfare, ${ }^{15}$ with a combination of indicators. ${ }^{16}$ Wellbeing measures, when done at regular intervals, can shed light on the impact of government expenditures in different sectors and can be instrumental in strengthening policies to keep up with constant labor market changes and new skills demands for future professions. Although a system of national wellbeing accounts should undergird any policy reform, it would, at this stage, be an ambitious undertaking for Georgia.

\section{CONCLUSION}

In this paper, we tried to show that creating socially-minded means (i.e., education policies) requires starting from explicit ends that have intrinsic value (i.e., individual and social wellbeing), thereby allowing for a diversity of means to reach that end. To achieve individual and social wellbeing in the context of Georgia, the most effective means would be changes in political and institutional practices, as well as advancements in social structures to improve people's capabilities towards leading individual and professional lives they have reason to value. By becoming a central element in Georgia's economy, the VET sector has the potential to initiate a stream of socially-minded structural changes, paving the way for a full operationalization of the capability approach.

\footnotetext{
${ }^{14}$ Gross Domestic Product. Defn: The total value of goods and services produced by a country in a year. See: Cambridge Dictionary (Finance and Economics). Accessed: 11 July, 2020.

15 Traditional economic measurements are not concerned with people's happiness. By assuming that people's preferences stay static over time, they focus on people's combined purchasing power, as articulated by Becker in his own time, omitting subsequent external effects that greatly influence wellbeing.

16 To create realistic indicators, forms of subjective wellbeing should be considered and incorporated, such as on-line and recall indicators (a person's ability to give an account of their current, as well as past feelings), and broad vs. narrow indicators (a person's established lifestyle, i.e.: work, vs. their daily experiences, i.e.: work relationships) (p. 141). For a broader description of wellbeing concepts, see: Table 7.1 (p. 143) in: Diener, E., \& Tov, W. (2012). National accounts of well-being. In K. C. Land, A. C. Michalos, \& M. J. Sirgy (Eds.), Handbook of social indicators and quality of life research. New York, NY: Springer.
} 
In order to look closer into the potential of some of these policy changes, we suggest some overtures for future research.

To refute the long-standing distrust between public and private actors and institutionalize collective intelligence, creating a joint legislative agency to coordinate WBL is the first step. Further steps could include setting up mechanisms like ALMPs or LMISs to improve standards and skills-matching further. Using the DACUM mechanism would ensure detailed translation from occupational to educational standards, supporting permanent skills adaptability.

For successful institutional reform, precarity in education and work must be rooted out. This can be done through smart regulation, ${ }^{17}$ which should be as simple as possible, but as strict as necessary, assigning clear roles and responsibilities, as well as potential ramifications in case of non-compliance.

Institutional reform would also benefit from more institutional autonomy, where colleges and local municipalities would be spared long interruptions in their work due to changes on highlevels of governance, bringing them closer to the needs of enterprises on the ground. Such setups would ideally be accompanied with regular quality checks.

To maximize the reach of the reform, formalization of the expansive, and often invisible, informal sector must be considered, by including informal enterprises in formal events and trainings. Likewise, including MSMEs with subsistence production in apprentice-training by creating economies of scale would allow them to decrease their cost per unit of output and increase their scale of operation. Government support for cooperatives and other forms of business associations should play a stronger role in the reform.

Other policies that account for people's wellbeing, as well as productivity, would be a healthy work-life balance and adequate salary for the work performed. Such decisions would foster domestic demand, benefiting the local economy. A wider use of the capability approach could go as far as designing macro level policies, such as introduction of progressive taxation or design of social re-integration policies, contributing further to individual and social wellbeing. While such insights are beyond the scope of this paper, a macro analysis of wellbeing policies could be an interesting consideration for further research.

\footnotetext{
17 For example, regulating simple ways for people to register their business (online and in person) and adhere to contractual rules and regulations to ensure non-precarious working standards. Instructions should be in nonlegal, widely comprehensible language, with a clear outline of terms and conditions.
} 


\section{REFERENCES}

Acemoglu, D., Johnson, S., \& Robinson, J. A. (2005). Institutions as the Fundamental Cause of Long-Run Growth. In P. Aghion, \& Durlauf, S. (Eds.), Handbook of Economic Growth. (Vol. 1A., pp. 385-472). San Diego \& Amsterdam: North Holland.

Acemoglu, D., \& Robinson, J. A. (2012). Why Nations Fail: The Origins of Power, Prosperity and Poverty. London: Profile.

ACT. (2019). Tracer Study of 2018 VET Program Graduates. Tbilisi, Georgia: MoESCS. http:// mes.gov.ge/content.php?id=5962\&lang=eng

Aleksynska, M. (2018). Temporary Employment, Work Quality, and Job Satisfaction. Journal of Comparative Economics, 46(3), 722-735.

Badurashvili, I. (2019). Skills Mismatch Measurment in Georgia. Turin, Italy: European Training Foundation.

https://www.etf.europa.eu/sites/default/files/2019-10/ skills_mismatch_measurement_georgia.pdf

Bardi, A.-M., \& Véran, J.-P. (2020). Vers une gouvernance apprenante. Revue internationale d'éducation de Sèvres, (83), 105-112.

Becker, G. S. (1993). Human Capital: A Theoretical and Empirical Analysis, with Special Reference to Education. Chicago, IL, \& London: The University of Chicago Press.

Béduwé, C., \& Mora, V. (2017). De la professionnalité des étudiants à leur employabilité, n'y a-t-il qu'un pas? Formation emploi, (2), 59-77.

Bell, L. A. (2007). Theoretical Foundations for Social Justice Education. In M. Adams, L. A. Bell, \& P. Griffin (Eds.), Teaching for Diversity and Social Justice (pp. 1-14). New York and London: Routledge.

Biavaschi, C., Eichhorst, W., Giulietti, C., Kendzia, M. J., Muravyev, A., Pieters, J., RodríguezPlanas, N., Schmidl, R., Zimmermann, K. F. (2012). Youth Unemployment and Vocational Training. IZA Discussion Paper, 6890, 1-103.

Blanchet, A., \& Gotman, A. (2015). L'entretien. Malakoff : Armand Colin.

Boltanski, L., \& Chiapello, E. (1999). Le nouvel esprit du capitalisme. Paris : Gallimard.

Boltanski, L., \& Chiapello, E. (2005). The New Spirit of Capitalism. International Journal of Politics, Culture, and Society, 18(3-4), 161-188.

Boltanski, L., \& Chiapello, È. (1999). The New Spirit of Capitalism (G. Elliott, Trans.). London, New York, NY: Verso.

Bourdieu, P., \& Passeron, J.-C. (2000). Reproduction in Education, Society and Culture. London: SAGE Publications.

Cedefop. (2015). Work-based Learning in Continuing Vocational Education and Training: Policies and Practices in Europe (publication n49). Luxembourg: Publications Office of the European Union. https://www.cedefop.europa.eu/files/5549_en.pdf

Champy-Remoussenard, P. (2015). Les transformations des relations entre travail, éducation et formation dans l'organisation sociale contemporaine: questions posées par trois dispositifs analyseurs. Revue française de pédagogie, (1), 15-28. 
De Ketele, J.-M. (2020a). Réformer l'éducation: travailler ensemble au bien commun en développant une intelligence collective. Revue internationale d'éducation de Sèvres, (83), 205-233.

De Ketele, J.-M. (2020b). Réformer l'éducation. Introduction. Revue internationale d'éducation de Sèvres, (83), 13-22.

De Kok, J., Deijl, C., \& Essen, C. V.-V. (2013). Is Small Still Beautiful? Literature Review of Recent Empirical Evidence on the Contribution of SMEs to Employment Creation.

https://www.ilo.org/wcmsp5/groups/public/---ed_emp/---emp_ent/---ifp_seed/ documents/publication/wcms_216909.pdf

Diener, E., \& Tov, W. (2012). National Accounts of wellbeing. In K.C. Land, A.C. Michalos, \& M.J. Sirgy (Eds.), Handbook of Social Indicators and Quality of Life Research (pp. 137-156). New York: NY: Springer.

ETF. (2019). Georgia: Education, Training, and Employment Developments 2019. Turin, Italy: European Training Foundation. https://www.etf.europa.eu/sites/default/files/document/ Country\%20fiche\%20Georgia\%202019.pdf

Fraser, N. (2004). Justice sociale, redistribution et reconnaissance. Revue du MAUSS, (1), 152-164.

Gegenava, D. (2017). Retrospection of the Constitutional Reforms of Georgia: In Search of the Holy Grail. South Caucasus Law Journal, 8, 237-243.

Government of Georgia. (2010). Organic Law of Georgia. Labour Code of Georgia. Tbilisi: Government of Georgia.

Government of Georgia. (2020a). Report on the Implementation of Vocational Education Action Plan 2019 for the Unified Strategy on Education and Science (2017-2021). Tbilisi: Ministry of Education, Science, Culture and Sport of Georgia. http://mes.gov.ge/uploads/ files/TVET\%20Annual\%20Report_2019\%20Year.pdf

Government of Georgia. (2020b). Social-economic Development Strategy of Georgia: Georgia 2020. Tbilisi: Government of Georgia. https://www.adb.org/sites/default/files/ linked-documents/cps-geo-2014-2018-sd-01.pdf

Grant, C. A., \& Gibson, M. L. (2013). 'The Path of Social Justice': A Human Rights History of Social Justice Education. Equity \& Excellence in Education, 46(1), 81-99.

Greif, A. (2006). Institutions and the Path to the Modern Economy: Lessons from Medieval Trade. Cambridge: Cambridge University Press.

Hennink, M., Hutter, I., \& Bailey, A. (2020). Qualitative Research Methods. London: SAGE Publications Limited.

Hickel, J. (2017). The Divide: A Brief Guide to Global Inequality and its Solutions. London: Penguin Random House.

Hickel, J. (2020). Less is More: How Degrowth Will Save the World. London: Penguin Random House.

ILO. (2016). Non-Standard Employment Around the World: Understanding Challenges, Shaping Prospects. Geneva: ILO. http://hdl.voced.edu.au/10707/417360 
ILO. (2019a). Small Matters. Global Evidence on the Contribution to Employment by the SelfEmployed, Micro-Enterprises and SMEs. Geneva: ILO. https://www.ilo.org/wcmsp5/ groups/public/---dgreports/---dcomm/---publ/documents/publication/wcms_723282.pdf

ILO. (2019b). Work for a Brighter Future. Geneva: ILO. http://hdl.voced.edu.au/ $10707 / 493395$

Jacobs, R. L. (2019). Work Analysis in the Knowledge Economy: Documenting What People Do in the Workplace for Human Resource Development. London: Palgrave Macmillan.

Klein, N. (2007). The Shock Doctrine: The Rise of Disaster Capitalism. New York, NY: Metropolitan Books.

La Porta, R., Lopez, F., Shleifer, A., \& Vishny, R. (1999). The Quality of Government. Journal of Law, Economics, and Organization, 15(1), 222-279.

Layard, R. (2005). Happiness: Lessons from a New Science. London: Penguin UK.

Ludwig-Mayerhofer, W., Solga, H., Leuze, K., Dombrowski, R., Künster, R., Ebralidze, E., . . . Kühn, S. (2011). Vocational Education and Training and Transitions into the Labor Market. Zeitschrift für Erziehungswissenschaft, 14(2), 251-266.

Martusewicz, R. A., Edmundson, J., \& Lupinacci, J. (2014). Ecojustice Education: Toward Diverse, Democratic, and Sustainable Communities. New York, NY: Routledge.

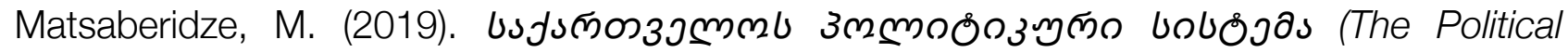
System of Georgia). Tbilisi: Ivane Javakhishvili Tbilisi State University.

Meuret, D. (2020). Légitimation et légitimité des réformes. Revue internationale d'éducation de Sèvres, (83), 113-121.

MoESCS. (2014). Labour Market Status of VET Graduates in Georgia: Analysis of Tracer Studies. Tbilisi: MoESCS. http://mes.gov.ge/content.php?id=5962\&lang=eng

MoESCS. (2015). VET Development Strategy of Georgia (2013-2020): 2015 Strategy Action Plan Implementation. Tbilisi: MoESCS.

https://mes.gov.ge/uploads/1.VET\%20STrategy_AP_EN.pdf

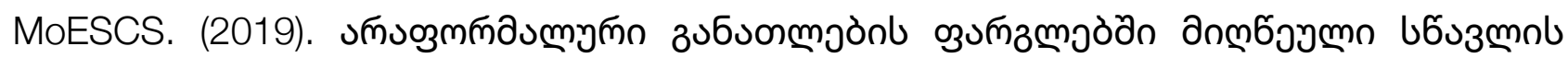

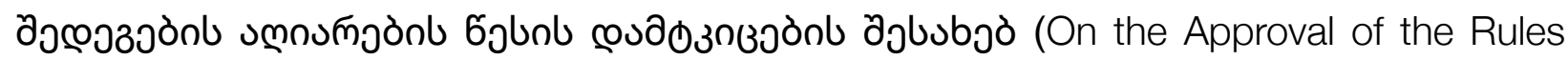
for the Recognition of Learning Outcomes Achieved within Non-formal Education). Tbilisi, Georgia: MoESCS.

ht t ps://eqe.ge/res/docs/

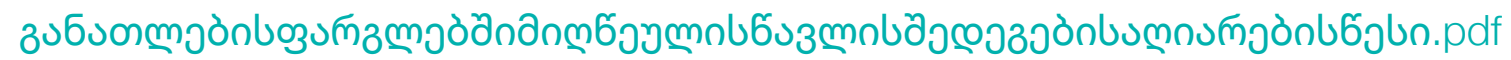

Moodie, G., Wheelahan, L., \& Lavigne, E. (2018, September 3-7). Productive Capabilities: A Framework for Vocational Education. Paper presented at the Trends in Vocational Education and Training Research. European Conference on Educational Research (ECER), Vocational Education and Training Network (VETNET), Bolzano, Italy.

Moodie, G., Wheelahan, L., \& Lavigne, E. (2019). Technical and Vocational Education and Training as a Framework for Social Justice: Analysis and Evidence from World Case Studies. Brussels: Education International. https://issuu.com/educationinternational/docs/ 2019_eiresearch_tvet

Nachtwey, O. (2016). Die Abstiegsgesellschaft: über das Aufbegehren in der regressiven Moderne. Berlin: Suhrkamp Verlag. 
NEF. (2009). National Accounts of wellbeing: Bringing Real Wealth onto the Balance Sheet. London: NEF. https://www.nefconsulting.com/wp-content/uploads/2017/10/nationalaccounts-of-well-being-report.pdf

North, D. C. (1990). Institutions, Institutional Change and Economic Performance. Cambridge: Cambridge University Press.

Norton, R. E., \& Moser, J. (2008). DACUM Handbook. Columbus OH: Center on Education and Training for Employment, The Ohio State University.

Nussbaum, M. C. (2011). Creating Capabilities. The Human Development Approach. Cambridge, MA: Harvard University Press.

OECD. (2019). Financing SMEs and Entrepreneurs 2019: An OECD Scoreboard. Paris: OECD Publishing.

Omanadze, S., Gachechiladze, N., Lebanidze, A., \& Chachanidze, S. (2017). Generation in Transition: Youth Study 2016-Georgia. Tbilisi: Friedrich-Ebert-Stiftung, South Caucasus Regional Office.

Palmer, R. (2020). Lifelong Learning in the Informal Economy: A Literature Review. Geneva: ILO.

http://www.oit.org/wcmsp5/groups/public/---ed_emp/---emp_ent/documents/publication/ woms_741169.pdf

Pilc, M. (2017). Cultural, Political and Economic Roots of the Labor Market Institutional Framework in the OECD and Post-Socialist Countries. Equilibrium. Quarterly Journal of Economics and Economic Policy, 12(4), 713-731.

Raphael, L. (2019). Jenseits von Kohle und Stahl: Eine Gesellschaftsgeschichte Westeuropas nach dem Boom. Berlin: Suhrkamp Verlag.

Robeyns, I. (2017). Wellbeing, Freedom and Social Justice: The Capability Approach ReExamined. Cambridge: Open Book Publishers.

Sen, A. (1990). Development as Capability Expansion. In K. Griffin, \& J. Knight (Eds.), Human development and the international development strategy for the 1990s (pp. 41-58). London: Macmillan.

Sen, A. (2000). Development as Freedom. New York, NY: Alfred A. Knopf, Inc.

Sen, A. (2005). Human Rights and Capabilities. Journal of human development, 6(2), 151-166.

Sepulveda, L., \& Syrett, S. (2007). Out of the Shadows? Formalisation Approaches to Informal Economic Activity. Policy \& Politics, 35(1), 87-104.

Shirley, D. (2020). Beyond wellbeing: The Quest for Wholeness and Purpose in Education. ECNU Review of Education, 3(3), 542-555.

Tumanishvili, G. G., \& Omsarashvili, D. (2016). Psycho-Social and Legal Aspects of Internship in Contemporary Georgia: Current Practice and Challenges. Justice and Law, 4(52), 37-56.

Tyson, R. (2016). What Would Humboldt Say: A Case of General Bildung in Vocational Education? International Journal for Research in Vocational Education and Training, 3(3), 230-249. 
Vardakoulias, O. (2013). Economics in Policy-making: Social CBA and SROI. London : NEF. https://www.nefconsulting.com/wp-content/uploads/2014/10/Briefing-on-SROI-andCBA.pdf

Winograd, K. (2016). Education in Times of Environmental Crises: Teaching Children to Be Agents of Change. New York, NY: Routledge.

Wittorski, R. (2008). La professionnalisation. Savoirs, (2), 9-36.

Wittorski, R. (2011). Les rapports entre professionnalisation et formation. Education permanente, (188), 5-10. 